\title{
STUDY OF SOME PHYSIOLOGICAL AND YIELD TRAITS OF TWO GINGER (ZINGIBER OFFICINALE ROSC.) CULTIVARS
}

\author{
E. C. NWACHUKWU
}

(Received 15 September 2016; Revision Accepted 15 February 2017)

\begin{abstract}
A comparative study on some physiological and yield traits of ginger was undertaken using two distinct ginger varieties, The experiments was laid out on flats in a randomized complete block design replicated five times and analysed as a split-plot experiment. The main-plot treatments were the two varieties and the sub-plot treatments were three sett sizes of the two varieties $(10 \mathrm{~g}, 20 \mathrm{~g}$ and $30 \mathrm{~g})$. Each sub-plot was a $2.4 \mathrm{~m} \times 0.5 \mathrm{~m}$ flat bed, each bed containing 20 setts planted at $20 \mathrm{~cm} \times 20 \mathrm{~cm}$ spacing. $U G_{1}$ and $U G_{2}$. The effects of sett sizes $(10,20$ and $30 \mathrm{~g})$ on these traits were examined. The number of shoots and leaf area per stand, plant height, rhizome yield and the number of rhizome fingers increased with sett size. $U G_{1}$ produced significantly more shoots and rhizome fingers per stand and was also higher yielding than $\mathrm{UG}_{2}$ which produced significantly taller plants, all at 0.05 probability level. There was no significant difference between the cultivars for leaf production. The physiological attributes for high yield in the ginger varieties included early foliage development and high yield capacity to channel dry matter into the rhizomes. High net assimilation rate (NAR) and relative growth rate (RGR) values did not ensure high yields.
\end{abstract}

KEYWORDS: Ginger, Zingiber officinale, growth parameters, RGR, NAR, LAR, yield

\section{INTRODUCTION}

The cultivation of ginger in Nigeria started around 1927 as an export crop. (Arene et. Al., 1987: Purseglove. 1972). In 1977, Nigeria exported 3071 tonnes of dry ginger compared to 4461 tonnes by India (Anard, 1982). However, work on the scientific basis for its production in Nigeria started in 1982 at the National Root Crops Research Institute, Umudike. The research objectives were centred around agronomic inputs to improve production. Improvement through breeding techniques started much later and is still at its infancy. In order to fully develop a sound breeding programme, there is the need to understand the biology of the crop. Yield for instance, is often influenced by a complex interaction of traits such as leaf area, plant height, leaf production, leaf arrangement, sources and sink capacity. A continuous goal is to identify physiological characters responsible for increased yield. The task would further be simplified if morphological and/or physiological traits associated with yield are identified. The yield of many root and tuber crops propagated by their stem tubers is influenced by the sett sizes used in establishing them (Onwueme, 1972), the cultural practice adopted and the inherent varietal differences. The physiological attributes of yield in ginger, however, have not been fully studied. It is possible that with vegetative characters as a guide, an early selection of promising clones could be made since selection per se is a long process by comparison with selection for some other important vegetative traits.

This study attempts a comparative evaluation of some physiological and yield traits of two varieties. $U_{1}$ (yellow ginger "Tafin Giwa") and $\mathrm{UG}_{2}$ (black ginger, "Yatsun Biri").

\section{MATERIALS AND METHOD}

The experiment was performed in the National Root Crops Research Institute, Umudike - Umuahia, for three years during the 2009, 2010 and 2011 early cropping seasons

In each year, the experiments were planted out during the first week of April and two distinct varieties of ginger $U G_{1}$ and $U G_{2}$ were used. The 2009 and 2010 experiments were laid out on flats in a randomized complete block design, replicated five times and analysed as a split-plot experiment. The main-plot treatments were the two varieties and the sub-plot treatments were three sett sizes of the two varieties (10 $\mathrm{g}, 20 \mathrm{~g}$ and $30 \mathrm{~g}$ ). Each sub-plot was a $2.4 \mathrm{~m} \times 0.5 \mathrm{~m}$ flat bed, each bed containing 20 setts planted at $20 \mathrm{~cm} \times 20$ $\mathrm{cm}$ spacing. The plots were mulched with dry grass and hand weeded when necessary. Data were collected on plant height, number of shoots per stand and leaf area per stand at 20 weeks after planting (WAP). Leaf area was estimated using the mathematical formula, $Y=$ $0.51 n L w+1.05 n+53.61$ as described by Nwachukwu and Ene (1987), where $Y$ is the leaf area per plant, $n$ is the leaf population per plant, $L$ is the leaf length and $w$ is the width at the widest point of the middle leaf. The rhizome fingers per stand were collected at harvest when the leaves started yellowing, 27 weeks after planting. Data collected were subjected to analysis of

E. C. Nwachukwu, National Root Crops Research Institute, Umudike. P.M.B. 7006, Umuahia. Abia State, Nigeria. 
variance and significant effects were separated using Fisher's Least Significant Difference (F-LSD) as described by Obi, (1986).

During the 2011 experiment, the two ginger variants, UG1 and UG2 were planted out in the field in two plots, replicated four times. Each plot was a $5 \mathrm{~m} \times 2$ $\mathrm{m}$ flat-bed containing 200 stands planted at $20 \mathrm{~cm} \times 20$ $\mathrm{cm}$ spacing. The ginger sett size used to establish each stand was $20 \mathrm{~g}$. The cultural practice was the same as in the 2009 and 2010 experiments. Data on growth characteristics of the ginger, were collected at two weekly intervals from $10-24$ WAP. At each sampling period, ten stands per plot were randomly selected and uprooted carefully, tagged and transported to the laboratory where growth parameters were taken. Water was used to remove soil from the roots and the rhizomes. Leaf area was estimated using the mathematical equation used in the 2009 and 2010 experiments. Each stand sample was separated into leaves, stalks, harvestable roots and rhizome. The various plant parts were weighed and then oven dried to constant weight at $80^{\circ} \mathrm{C}$.

The primary data for leaf area and plant dry weight measurements were used to calculate the net assimilation rate (NAR), leaf area ratio (LAR), and relative growth rate (RGR). The rhizome: top growth weight ratio was also computed. Net assimilation rate was calculated as:

$\mathrm{NAR}=\left\{\frac{\mathrm{W}_{2}-\mathrm{W}_{1}}{\mathrm{t}_{2}-\mathrm{t}_{1}} \times \frac{\log _{\mathrm{e}} \mathrm{A}_{2}-\log _{\mathrm{e}} \mathrm{A}_{1}}{\mathrm{~A}_{2}-\mathrm{A}_{1}}\right\}^{\mathrm{gdm}^{-2} \mathrm{Wk}^{-1}}$

where $W_{1}$ and $W_{2}$ are the mean dry weights per stand, $A_{1}$ and $A_{2}$, the total leaf area per stand between two sampling times, $t_{2}-t_{1}$, the duration in weeks between the initial $\left(t_{1}\right)$ and final $\left(t_{2}\right)$ sampling times.

Leaf area ratio (LAR) was calculated as

$$
\mathrm{LAR}=\sqrt[1]{2}\left[\frac{\mathrm{A}_{1}}{\mathrm{~W}_{1}}+\frac{\overline{\mathrm{A}_{2}}}{\mathrm{~W}_{2}}\right] \mathrm{cm}^{2} \mathrm{~g}^{-1}
$$

Relative growth rate was calculated as: $R G R=L A R x$ NAR (Radford, 1967).

\section{RESULTS AND DISCUSSION}

The 2009 and 2010 results were similar therefore only the 2009 and 2011 results are presented.

The results showed that the quantitative characters considered (the number of shoots per stand, leaf area, plant height, rhizome fingers per stand), increased in value with increased sett size (table 1).

This is in conformity with an established relationship between sett size and most of these vegetative characters, in root and tuber crops that are propagated through their stem tubers (Onwueme, 1972: lyonga et al 1973 and Nwoke et al, 1973) Omenukor (1983) and Okwuowulu (1988) observed the same trend in ginger. According to these authors, large setts possessed more sprouting loci and produced more sprouts per sett than smaller setts.

Also large setts produced more vigorous plants than smaller setts and therefore were taller, produced more leaves and had higher yielding ability than plants from smaller sett sizes. $U_{1}$ produced significantly at $p=0.05$, more number of shoots per stand, rhizome fingers per stand and was higher yielding than $\cup_{2}$ which produced significantly at $p=0.05$, taller plants. The leaf area was similar for the two cultivars.

Table1: The effect of sett size on the mean of some quantitative and vegetative characters of two cultivars of ginger at National Root Crops Research Institute, Umudike in 2009 and 2010.

\begin{tabular}{|c|c|c|c|c|c|c|c|}
\hline \multirow{2}{*}{$\begin{array}{l}\text { Quantitative } \\
\text { Character }\end{array}$} & \multicolumn{3}{|c|}{ Sett Size (g) } & \multirow{2}{*}{$\begin{array}{l}\text { LSD } \\
(p=0.05) \text { for } \\
\text { sett size }\end{array}$} & \multicolumn{2}{|c|}{ Cultivar } & \multirow{2}{*}{$\begin{array}{l}\text { LSD }(0.05) \\
\text { for cultivar } \\
\text { mean }\end{array}$} \\
\hline & 10 & 20 & 30 & & $\mathrm{UG}_{1}$ & $\mathrm{UG}_{2}$ & \\
\hline No. shoots per stand & 4.0 & 5.0 & 5.5 & 1.10 & 5.2 & 4.7 & 0.25 \\
\hline $\begin{array}{l}\text { Leaf area per stand } \\
(\mathrm{cm})^{2}\end{array}$ & 2382.56 & 2517.4 & 3355.09 & 433.7 & 2614.15 & 2889.2 & Ns \\
\hline \multicolumn{8}{|l|}{ Plant height $(\mathrm{cm})$} \\
\hline $\begin{array}{l}\text { Rhizome yield per } \\
\text { stand }(\mathrm{g})\end{array}$ & 62.3 & 69.7 & 70.75 & 4.11 & 58.57 & 78.6 & 3.62 \\
\hline \multirow[t]{2}{*}{$\begin{array}{l}\text { No. rhizome fingers } \\
\text { per stand }\end{array}$} & 121.6 & 140.0 & 209.7 & 20.45 & 181.9 & 132.9 & 23.04 \\
\hline & 5.2 & 5.5 & 5.8 & 0.15 & 5.8 & 5.1 & 0.3 \\
\hline
\end{tabular}

$\mathrm{Ns}=$ not statistically significant at $\mathrm{p}=0.05$ 
The 2011 results on growth parameters of the two ginger varieties also showed that $U_{2}$ had higher NAR and RGR values during the periods of 10 to 18 WAP (Table 2) after which their values were similar. Their LAR values however were similar.

Since RGR is a product of NAR and LAR, the reasonably higher $R G R$ value obtained for $U G_{1}$ may have been as a result of the higher NAR values for those periods as against low values for $U G_{2}$. Pandey et al (1978) found significant genotypic differences in RGR and NAR in Vigna Mango varieties and it is possible that the differences observed may be inherent in the ginger varieties. UG1 has higher economic yield (rhizome yield) than $U_{2}$, (Table 1).

By the $10^{\text {th }}$ week when the stands had become properly established, the stalks and leaves recorded the highest weights in both varieties.

Table 2: The net assimilation rate (NAR), leaf area ratio (LAR) and the relative growth rate (RGR) of two ginger cultivars UG1 and UG2 with age at National Root Crops Research Institute, Umudike in 2011.

\begin{tabular}{lllllll}
\hline Age (WAP) & \multicolumn{2}{l}{ NAR } & $\left(\mathrm{g} \mathrm{dm}^{-2} \mathrm{wk}^{-1}\right)$ & \multicolumn{2}{c}{ LAR $\left(\mathrm{cm} 2 \mathrm{~g}^{-1}\right)$} & \multicolumn{2}{c}{ RGR $\left(\mathrm{gg}-1 \mathrm{wkj}^{-1}\right.$} \\
10 & UG1 & UG2 & UG1 & UG2 & UG1 & UG2 \\
12 & - & - & - & - & - & - \\
\hline 14 & .23 & .59 & 135 & 165 & .31 & .97 \\
16 & .15 & .39 & 122.5 & 135 & .18 & .53 \\
18 & .14 & .26 & 125 & 127.5 & .18 & .33 \\
20 & .14 & .31 & 115 & 117.9 & .16 & .37 \\
22 & .11 & .13 & 102.5 & 117.5 & .11 & .19 \\
24 & .08 & .06 & 85.4 & 105 & .07 & .06 \\
S.E & .06 & .05 & 68.6 & 83.4 & .04 & .04 \\
\hline
\end{tabular}

S.E - standard error

WAP - weeks after planting.

NAR - Net Assimilation Rate

LAR - Leaf Area Ratio

RGR - Relative Growth Rate

However, the values for the various plant parts were significantly higher in UG1 than UG2 especially with the leaf weights. This was further apparent when the leaf area figures (Table 3) of the two varieties were compared. UG1 showed consistently higher leaf production from the $10^{\text {th }}$ week to about the $16^{\text {th }}$ week after which the differences in their leaf areas were not very apparent. Also, there was a marked increase in dry matter accumulation to the rhizomes in both varieties.
By the $18^{\text {th }}$ week, most of the dry matter were being channeled into the rhizomes. However the dry matter distribution into the rhizomes were higher in $U_{1}$ than in $U_{1}$. When the rhizome: top growth dry weight ratios (Table 3 ) of both varieties were compared. $U G_{1}$ was found to have higher ratios especially from the $16^{\text {th }}$ week, indicating that $U_{1}$ was more efficient in the distribution of photosynthetic assimilates into the economic part than $\cup_{2}$.

Table3: The leaf production and rhizome: top growth ratio of two ginger cultivars $\left(U_{1}\right.$ and $\left.U G_{2}\right)$ with age (WAP) at National Root Crops Research Institute, Umudike in 2011.

\begin{tabular}{lllllll}
\hline Age (WAP) & \multicolumn{2}{l}{ Leaf area } & \multicolumn{3}{l}{ Rroduction $\left(\times 10^{2}\right)$} & \multicolumn{3}{l}{ Rhizome : Top Growth Ratio } \\
& $\mathrm{UG}_{1}$ & $\mathrm{UG}_{2}$ & $\mathrm{SE}$ & $\mathrm{UG}_{1}$ & $\mathrm{UG}_{2}$ & $\mathrm{SE}$ \\
10 & 2.1 & 2.1 & 1.0 & 2.1 & 2.0 & 0.2 \\
12 & 6.2 & 2.8 & 1.0 & 2.7 & 2.3 & 0.3 \\
\hline 14 & 10 & 4.2 & 1.2 & 2.6 & 2.5 & 0.2 \\
16 & 14.4 & 6.4 & 1.6 & 3.2 & 2.6 & 0.3 \\
18 & 17 & 8.0 & 2.0 & 4.8 & 3.0 & 0.3 \\
20 & 23.4 & 8.2 & 3.6 & 6.5 & 4.2 & 0.6 \\
22 & 24.2 & 9.2 & 3.8 & 11.8 & 6.0 & 1.5 \\
24 & 24.6 & 10.2 & 4.0 & 16.0 & 10.3 & 1.8 \\
\hline
\end{tabular}


The higher economic yielding capacity of $\mathrm{UG}_{1}$ as against $U_{2}$ might be due to several reasons. Foremost may be how fast leaf canopy was developed. $U_{G_{1}}$ developed an earlier and larger leaf area than $U_{G_{2}}$. This was maintained for a longer period thus ensuring longer leaf area duration. The amount of leaf coverage determines among other factors, the dry matter accumulation and yield of crops (Watson, 1956). Doku (1965) reported that clones of cassava that gave high yields had the ability to retain a large leaf area and Enyi (1972) reported a positive relationship between leaf area duration and root yield in tuber crops. In the yams, Cornet et. al. (2014) concluded, that early leaf emergence proved to be the primary factor leading to high tuber yields,

The more efficient channeling of dry matter into the rhizome of $U G_{1}$ than $U G_{2}$ may also account for the higher yields recorded in $U_{G_{1}}$. However, $U_{2}$ maintained denser and taller vegetation than $\mathrm{UG}_{1}$ and it was possible that $\mathrm{UG}_{2}$ used more photosynthetic assimilates to maintain vegetative structure. The physiological attributes for high yield in the ginger include early foliage development and the capacity to channel dry matter into the rhizomes.

\section{REFERENCES}

Anard, N., 1982. Selected markets for ginger and its derivatives with special reference to dried ginger Tropical products Institute, London. U.K. 106.

Arene, O. B., Okwor, G. C and Okwuowulu, P. A., 1987. Ginger Research in Nigeria. Proc. $3^{\text {rd }}$ Triennial Symp, Inter, Soc. Trop. Root Crops - Africa Branch $89-93$.

Cornet D., Sierra J and Tournebize R., 2014. Yams (Dioscorea. Spp,). Plant size hierarchy and yield variability: Emergence time is critical. European Journal of Agronomy, 55:100-107.

Doku, E, V., 1965. Breeding for yield in cassava. I. Indices of yield Ghana J. of Science 5 (1):42 59

Enyi, B. A. C., 1972. The effects of spacing on growth development and yield of single and multi-shoot plants of cassava (Manihot esculenta) Crantz). 11. Physiological factors. East Africa. Agric. For. J.) b38: $27-34$.

Lyonga, S. N., Fayemi, A. A and Agboola. A. A., 1973. Agronomic studies on edible yams (Dioscorea spp) in the grassland plateau region of the United Republic of Cameroun, $3^{\text {rd }}$ Intern. Symp. Trop. Root Crops, Ibadan Nigeria.
Nwachukwu, E. C and Ene, L. S. O., 1987. Rapid method of estimation of leaf area of ginger (Zingiber officinale Rosc.) from non-destructive measurements. Nigeria J. of Agron. 2 (2): 50 53.

Nwoke, F. I. O., Njoku, E and Okonkwo, S. N. C., 1973. The effect of size of seed yams on yield of individual plants of Dioscorea rotundata. Proc. $3^{\text {rd }}$ Intern. Symp. Trop. Root Crops. Ibadan, Nigeria.

Obi, I. U., 1986. Statistical Methods of detecting differences between treatment means SMAPP Press. Enugu, Nigeria. Pp. 45.

Okwuowulu, P. A., 1988. Effects of seed-ginger weight on the flowering and rhizome yield of field grown edible ginger (Zingiber) Trop. Sci. 28: 171 176.

Omenkor, R. C., 1983. The effect of spacing, seed weight and time of planting on the yield of ginger, Ann. Rep. National Root Crops Research Institute, Umudike. Nigeria. 196pp.

Onwueme, I. C., 1972. Influence of the weight of the planted tuber on the vegetative performance of white yam (Dioscores rotundata pior) plants. Niger. Agric. J. 9: 170 - 177.

Pandey, R. K., saxena, M. C and Singh. V. B., 1978. Growth analysis of black gram genotypes. Indian J. Agric. Sci. 48: 466 - 473.

Purseglove, J. W., 1972. Tropical Crops Monocotyledons 2. Longmans Green and Co. London. 533 - 540

Radford, P. J., 1967. Growth and analysis formulae Their use and abuse. Crop Sci. 7: 171 - 175

Watson, D. J., 1956 leaf growth in relation to crop yield, growth of leaves. Proc. $3^{\text {rd }}$ Easter School Agric. Sci. Univ. Nottingham 178 - 191. 